Journal of Hospitality and Tourism Management

http://journals.cambridge.org/JHT

Additional services for Journal of Hospitality and Tourism Management:

Email alerts: Click here

Subscriptions: $\underline{\text { Click here }}$

Commercial reprints: $\underline{\text { Click here }}$

Terms of use : $\underline{\text { Click here }}$

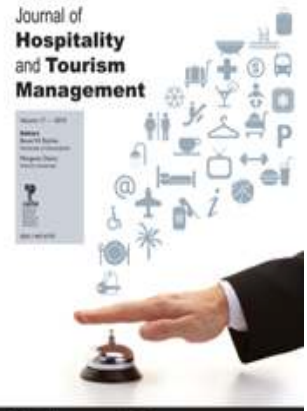

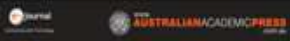

\title{
Tourism and Hospitality Research Student Experiences: How to Achieve Quality, Inclusivity and Belongingness
}

Gayle Jennings, Ulrike Kachel, Sandra Kensbock and Mary-Anne Smith

Journal of Hospitality and Tourism Management / Volume 16 / Issue 01 / December 2009, pp 139 - 147

DOI: 10.1375/jhtm.16.1.139, Published online: 23 February 2012

Link to this article: http://journals.cambridge.org/abstract_S1447677000000577

How to cite this article:

Gayle Jennings, Ulrike Kachel, Sandra Kensbock and Mary-Anne Smith (2009). Tourism and Hospitality Research Student Experiences: How to Achieve Quality, Inclusivity and Belongingness. Journal of Hospitality and Tourism Management, 16, pp 139-147 doi:10.1375/jhtm.16.1.139

Request Permissions : $\underline{\text { Click here }}$ 


\section{Tourism and Hospitality Research Student Experiences: How to Achieve Quality, Inclusivity and Belongingness}

\author{
Gayle Jennings, \\ Ulrike Kachel, \\ Sandra Kensbock and \\ Mary-Anne Smith \\ Griffith University, Australia
}

\begin{abstract}
What constitutes a quality research student learning experience? Using an interpretive social sciences approach, the tradition of autoethnography and the interpretive processes of reflexivity and constructivist grounded theory, the individual and collective lived research student experiences of three students were constructed/interpreted and (re)constructed/(re)interpreted to provide insights into answers to this question. Each student had completed one research program and, at the time of publication, was currently enrolled in a doctoral program. Based on these three students' autoethnographies, quality research student experiences engender personal, social, supervisor, research profession, learning communities and other life connectivities. These connectivities are generated through conducive conditions for learning, communities of practice and inclusive research cultures wherein research students experience and do research in order to become researchers, and to belong to research communities.
\end{abstract}

Keywords: autoethnography, interpretive social science, reflexivity, constructivist grounded theory, quality, connectivities, communities of practice
The purpose of this article is to contribute to furthering understandings of the processes and praxes that contribute to quality learning/teaching engagements and experiences for research students. Why such a focus? Because extant literature reports a number of areas continue to require redress within the multiple learning and teaching experiences of research students. These include a lack of cohort experiences, a sense of belonging to a research culture, as well as the building of strong and supportive research cultures. These are important areas for consideration, for it is from these learning/teaching experiences and research cultures that research students acquire 'socialisation' in regard to the professions in which they wish to enter (Trocchia \& Berkowitz, 1999) - in this case the profession of 'research'. Subsequently, elements of pedagogy, andragogy and ethnogogy require (re)consideration and reflection due to their roles in research culture 'building', research socialisation opportunities and experiences as does the perceived nature of the 'quality' of each of these.

Relatedly, conducive learning environments are critical components of generating learning communities that serve to build research students' identity - sense of self as researcher and professional. Cambourne (1984) frames

\section{Correspondence}

Gayle Jennings, Tourism, Leisure, Hotel and Sport Management, Griffith Business School, Gold Coast campus, Griffith University, Gold Coast QLD 4222, Australia. E-mail: g.jennings@griffith.edu.au seven pedagogical elements of conducive environments based on a sociolinguistic approach: immersion, demonstrations, time for approximation, timely provision of feedback, time and opportunity to practise, clear expectations of learning, models of applications in 'real world' as opposed to educational settings and contexts. These elements have strong synergy with ways to promote and sustain learning organisations (training and development) and organisational learning (embeddedness/role of culture in learning), see Senge et al. (1999).

Similarly, andragogical (adult learning) functions associated with lifelong learning are also necessary considerations for structuring learning environments (Knowles, 1984, 1990); as are ethnogogical functions - the teaching of students from differing cultural backgrounds (Phillips, 1994). As this article will demonstrate, synthesis of these principles in research student learning experiences serves to enhance and further strengthen research culture by simultaneously building and generating a sense of communitas among all involved in research training activities.

In particular, communitas is critical as it iterates the social context of learning, which is reflected in the research process for it 'is a social one, and students' hopes, fears, and concerns are at the heart of their experience of their research training' (Piercy et al., 2005, p. 378). Relatedly, communities of practice (Wenger, 1998) carry a similar social theory emphasis in regard to learning teaching experiences. Communities of practice link community (belonging), identity (becoming), meaning 
(experiences), and practice (doing) to develop professionbased learning experiences and skilling for students and subsequently have culture and cohort belongingness embedded in their praxis.

Within related academic literature, there is further support for building supportive, inclusive research cultures and the provision of profession-based learning/socialisation experiences for research higher degree (RHD) students, as well as how these enhance overall quality of learning and teaching. For example, Deem and Brehony (2000) discuss issues related to the degree that domestic and international, full-time and parttime, female and male students have the ability to 'access' research cultures within the organisational groupings and the institution in which they are enrolled. Offstein, Larson, and McNeill (2004) examined the lived experiences of fulltime graduate students and found that stress was intense, which was exacerbated by conflicting internal and external demands on students, time limits as well as student personalities. Moreover, the writers/researchers commented that stress levels were much higher for international students. To counterbalance this stress, Pondy (1989) discussed the need for effective student-supervisor relationships and the building of a 'common horizon', which we call communitas. Similarly, Conrad (2006, 2003) and Hortsmanshof and Conrad (2003) provide additional insights into engendering culture related to supervision experiences and postgraduate peer support programs.

At the core of the literature is emphasis on the social nature of research higher degree experiences and the need for construction of communitas, which has strong linkages to communities of practice. Focusing on a sense of communitas helps to work at the 'basic underlying assumptions' (Schein, 1992) of culture; that is, core beliefs, feelings, perceptions and thoughts and this is where communitas is critical in research culture formation and profession-based learning.

We have just provided a definition of culture, we recognise that culture is a complex term to define (Groseschl \& Doherty, 2000) and is always being reconstructed through social processes. For the purposes of this study, the term culture is deemed to also be socially constructed and promotes and provides a sense of community or communitas (Turner, 1969; Turner \& Turner, 1978) that is supportive and inclusive, attendant to identity issues and socialises for the profession. Profession is interpreted here as research-related 'vocations', such as, academia, business and industry. Finally, we have referred to quality and we acknowledge that it is a 'self-defined term' (Jennings \& Weiler, 2006, p. 59) embedded in the user/speaker's meanings, which are continuously socially (re)constructed and (re)interpreted.

\section{Tourism and Hospitality Research Student Experiences: Study Purpose}

The majority of tourism, travel and hospitality literature carries a post/positivistic research agenda. Subsequently, this article provides complementary insights from an interpretive social sciences approach. In particular, the tradition of autoethnography is and was used to fore- ground the nature of research student experiences. This approach was taken due to our focus on research student experiences, research cultures and learning/teaching engagements, along with acknowledgment of diversity in research student cohorts and their multiple needs. Consequently, our focus is on verstenhen (understanding) as opposed to erklären (explanation; see Jennings, 2009). The interpretive social sciences paradigm and the tradition of autoethnography were chosen as the best lenses to achieve such understanding by enabling research students to give 'voice' to and co-interpret their research experiences, perceptions of research culture and learning/teaching experiences. Additionally, because of the multiplicity of student experiences and needs, the interpretive social sciences paradigm was again considered the best fit paradigm since it provides in-depth localised and situated knowledge. The goodness of fit of the localised, situated knowledge theorised in this article will be determined by how well the lived experiences self-reported in this article resonate with other readers.

To iterate, the purpose of this study is to understand the processes and praxes that contribute to quality learning and teaching engagements and experiences for research students. The three research students who participated in this study all have longitudinal experiences across honours, bachelor/master's and doctoral degree experiences, either continuously at one university or sequentially in three institutions. Two of the research students are domestic and one is an international research student. The study context is temporally framed from 2005-2009 as well as being spatially located within two eastern Australian seaboard universities. At the time of writing this article, all three students were current doctoral candidates. Drawing on grounded interpretations of student autoethnographies, the article highlights praxis strategies, which (1) engender quality research student experiences, (2) emphasise inclusivity and belongingness and (3) offer research profession-based learning. Associated with these praxis strategies are considerations of the nature of research cultures within university and other research-related institutions.

\section{Study Significance}

By focusing on research culture, research professionbased learning and quality, this study is particularly important given the contexts of changing university environments both within and without Australia regarding 'quality' measures. In 1986, the United Kingdom established a quality assessment tool: the Research Assessment Exercise (REA), which in turn influenced subsequent Australian 'quality' measurement tools. The current tool, Excellence in Research for Australia (ERA) and the previous Australian Research Quality Framework (RQF) emphasise a shift from research quantity to quality measurements. The ERA subsequently has consequences for the nature of the quality of RHD students' lived learningteaching experiences - identity, belongingness and research profession socialisation and related quality outputs - particularly, on-time completions and quality journal publications. In addition, the Australian tertiary 
education landscape is punctuated by the Australian Universities Quality Audit (AUQA), which has an inputoutput focus. In relation to AUQA, a 'quality' research culture also has implications for on-time completions, student retention, student satisfaction and institutional reputational enhancement.

It is against this setting that this research study arose. The article's purpose has already been stated. In the course of pursuing that purpose, the article seeks to specifically address the following questions: How do we as tourism, travel and hospitality educators generate research student experiences that engender quality inclusivity and belongingness? How effectively do we socialise research students to become research professionals? How do we generate a positive research culture for research students to experience? While we ask these questions based on the external forces driving tertiary research education agendas, we also ask these questions because of the service nature of education. Our students are our clients, our customers, our consumers. That being said, we should not lose sight of the fact that the students are students and education situates itself somewhat differently to other service industries since it is heavily linked to a number of socialising institutions of cultures, societies and organisations. Like other service industries purchasers, each is different. So how do we tailor learning experiences that address such individuality, which is inherent in RHD student experiences? One way, as already mentioned, is to use autoethnography to gain deeper insight into the nature and quality of students' lived research experiences. Through this process, we are able to engage in sense and meaning-making with and between the research students with whom we build knowledge and understanding.

\section{Methodology}

Autoethnography and reflexivity are the key research processes that inform this article. Autoethnography has roots in an interpretive social sciences approach. Autoethnography 'keep[s] both the subject (knower) and the object (that which is to be examined) in simultaneous view' (Schwandt, 2001, p. 13). Similarly, it has been described by Cloke, Crang and Goodwin (1999, p. 333) as 'the process by which the researcher chooses to make explicitly use of [her or his] own positionality, involvements and experiences as an integral part of ethnographic research'. An alternate definition is provided by Pratt (1992, p. 7): autoethnographies 'refer to instances in which colonised subjects undertake to represent themselves in ways that engage with the coloniser's own terms ... autoethnography involves partial collaboration with and appropriation of the idioms of the conqueror'. It is more within the first of the two definitions that our use of autoethnography is situated. The use of autoethnography is not extensive in tourism, travel and hospitality literature. Albeit autoethnography is not a hegemonic methodological tradition, we do have access to partial autoethnographies when researchers provide insights into their positionality and social situatedness in their research writings. Table 1 provides a snapshot of autoethnographies in tourism, travel, hospitality and leisure related literature. The use of autoethnography, as demonstrated in Table 1 , is associated with autoethnography as reflexive practice with regard to the nature of tourism research inquiry and methods, self identity and mobilities, as well as othering processes.

Table 1

Snapshot of Autoethnographies in Tourism, Travel, Hospitality and Leisure Related Literature*

\begin{tabular}{|c|c|c|}
\hline Author and year* & Title of work & Focus \\
\hline Pratt (1992) & Imperial eyes: Trave/ writing and transculturation & $\begin{array}{l}\text { Definition of autoethnography provided. Considers transculturation } \\
\text { and travel writing and responses to othering. }\end{array}$ \\
\hline Alsop (2002) & Home and Away: Self-reflexive autoethnography & $\begin{array}{l}\text { Authoethnography used to explore the notions related to mobilities: } \\
\text { especially 'home', 'away', 'homesickness' and othering. }\end{array}$ \\
\hline Botterill (2003) & $\begin{array}{l}\text { An autoethnographic narrative on tourism } \\
\text { research epistemologies }\end{array}$ & $\begin{array}{l}\text { Autoethnographic narrative that reflects on tourism research with } \\
\text { regard to traditional ontology, epistemology and methodology for } \\
\text { understanding tourism phenomena. The author advocates the use } \\
\text { of critical realism. }\end{array}$ \\
\hline Pelias (2003) & The academic tourist: An autoethnography. & $\begin{array}{l}\text { Autoethnographic study of academic inquiry theorised as being akin } \\
\text { to tourists' inauthentic understandings of the 'others', upon which } \\
\text { they inquire. }\end{array}$ \\
\hline Morgan \& Pritchard (2005) & $\begin{array}{l}\text { On souvenirs and metonymy: Narratives of memory, } \\
\text { metaphor and materiality }\end{array}$ & $\begin{array}{l}\text { Researchers self-discuss their lived experiences through a series of } \\
\text { extended conversations that were interpreted with respect to the } \\
\text { nature of souvenirs, 'self-identity', 'place' as well as 'tourism } \\
\text { performance'. }\end{array}$ \\
\hline Westwood (2005) & $\begin{array}{l}\text { Out of the comfort zone: Situation, participation and } \\
\text { narrative interpretation in tourism research }\end{array}$ & $\begin{array}{l}\text { Conference paper, using autoethnography to draw on her doctoral } \\
\text { study of 'tourist-brand relationships' as a means to demonstrate } \\
\text { nonhegemonic tourism research methods such as 'auto- } \\
\text { ethnography'. }\end{array}$ \\
\hline Fleming \& Fullagar (2007) & $\begin{array}{l}\text { Reflexive methodologies: an autoethnography of the } \\
\text { gendered performance of sport/management }\end{array}$ & $\begin{array}{l}\text { Autoethnography is used as a reflexive methodology to determine } \\
\text { the 'social forces' that influenced the authors' leisure and } \\
\text { 'professional careers'. }\end{array}$ \\
\hline Harden (2007) & $\begin{array}{l}\text { Identities in motion: An autoethnography of an African- } \\
\text { American woman's journey to Burkina Faso, } \\
\text { Benin, and Ghana }\end{array}$ & $\begin{array}{l}\text { Doctoral research using autoethnography to understand African- } \\
\text { American identity when travelling through the United States. }\end{array}$ \\
\hline
\end{tabular}


As a complement to autoethnography, reflexive praxis (reflexivity) was also utilised. Reflexivity is: 'about "ways of seeing which act back on and reflect existing ways of seeing"' (Clegg \& Hardy, 1996, p. 4, cited in Alvesson \& Sköldberg, 2000, p. 248). In this study, the generation of reported experiences was facilitated by reflexive journals and focused conversations in face-to-face mode as well as e-mode in order to (re)interpret the research students' experiences. The lived experiences of research culture and related profession-based learning that emerged were reflexively (re)constructed by and grounded in the lived experiences of the study participants, that is, three research students. Based on the empirical materials generated in the course of this study, three lived experiences narratives are presented. Each represents an autoethnography. With regard to autoethnographies, it is not the number of autoethnographies that is important, but rather the richness and depth of understanding achieved concerning the lived experiences; both individually and collectively in the case of this article. The article now turns to the individual narratives of research student experiences, which have been reflexively framed. Each is presented in turn, before focusing on individual and collective emblematic themes inherent in their narratives.

\section{Research Student Lived Experience 1: From Bachelor Honours to PhD}

My experiences as an honours student within a conventional higher educational institution in Australia highlight the importance of a knowledgeable and astute supervisor who encourages inclusivity and reciprocal exchanges with peers. I was a 'very' mature-aged student from a lower socioeconomic background. I approached my honours degree with excitement in my expectations and trepidation in my abilities. I was fortunate to receive great support from other students who had been through, or were undergoing the honours process. Their assurances that it was 'do-able' helped my confidence in my ability to undertake the honours process. This peer encouragement also gave me a sense of inclusion and belonging. Initially, I experienced difficulties in finding a supportive supervisor and this negative experience, combined with external pressures of low economic resources as well as looking after a son with a disability, resulted in my withdrawal from the honours program.

Fortunately for me, there were two women who were instrumental in encouraging continuation of my academic learning. A young woman from the Marketing Department was enthusiastic about my potential and urged me on several occasions to re-enter the honours program, and I owe her a debt of gratitude. I was also extremely fortunate to find a new supervisor who was active in encouraging and aiding my continued learning. This associate professor was receptive to my proposed study, was supportive, approachable and friendly. She encouraged my intellectual development to expand my theoretical and methodological understanding and adopted a collaborative approach with an emancipatory agenda focused on my self-actualisation. This very knowledgeable and experienced woman demonstrated an astonishing commitment to my research needs. She encouraged my participation in active reflection so I was conscious of the learning that I was undergoing, and this provided an avenue for re-evaluation of my own values and perspectives. Under the guidance of this supervisor I relished broadening my intellectual knowledge and developing my understanding of sociology. The professional approach of my supervisor provided inspiration and an exemplary role model for selfcultivation of an ethical approach that was a quality research experience for me.

After my initial participation in an honours program where I experienced intense stress due to a 9-month 'honours' time limit deadline, I decided to spread my honours process over 2 years to enable competent completion of my qualitative research. I was also uncomfortable with feelings of a 'being in a race' to develop a career and get the 'piece of paper'. I had need of self-improvement that required an ultimate evaluation of having learned something. My personal experiences included a rollercoaster of emotions of feeling incompetent and unable to 'see the wood for the trees', to a sense of achievement when finished. I also often felt very proud of my developing sociological understandings and surprise at how much literature I had actually read. My supervisor encouraged me to keep a 'reflexive journal' that I found useful to document my personal journey and keep track of my developing understandings. I found the need for regular entries, at times, a little difficult as I had spent my whole life without keeping a diary or journal. My supervisor also encouraged my attendance at many visiting lecturers' presentations. The opportunity to meet many published authors brought the text books to life and added to a 'knowing' experience. I will carry to my grave my gratitude to this associate professor whose pedagogical approach enabled a profound broadening of my intellectual path on a personal level and as a career avenue. I am also humbled by her assurance that there was something reciprocal occurring as it was also a learning experience for her!

My supervisor also encouraged my involvement in 'research dialogue' sessions with other students and academics. These monthly meetings had a fluid membership and were attended by people from many different countries of origin and at varying stages of their research. These informal dialogue sessions had a powerful impact on my understanding of academic processes and were instrumental in raising my methodological and theoretical awareness through sharing understandings, as well as any encountered difficulties or problems. I relished these opportunities for theoretical advancement and found that my involvement with this cohort of experienced and new researchers was a significant socialisation process that engendered feelings of 'belonging' and fostered a research culture community within our department. Among the many positive outcomes of my involvement in these relaxed research dialogue sessions was my perception of being involved in a solid research community based on an open culture. I felt I could ask things that 'I should know' or was too timid to ask in other situations. These dialogue sessions fostered strong praxis strategies through immersion in varying topics that were pertinent to each 
researcher's progress. These dialogue sessions also provided a focal point for sharing understandings of philosophical perspectives that inform qualitative research, as well as methodologies and analysis techniques that could improve my research. This community of research practice enabled interactive communication and sharing of information that facilitated our expression of 'ontological' and 'epistemological' perspectives and aided development of our theoretical understandings.

This profession-based learning culture was invaluable in providing strong learning interactions, developing a peer-assisted culture among participants and allowed opportunities for dialogue among students that were usually busily engaged with their research in isolation 'behind closed doors'. This interaction developed to an extent where peers would hand over any articles that they thought might be relevant to my research. My involvement in this research dialogue group provided a holistic research experience for me and developed a participant relational circle among participants. These meetings and sharing of knowledge laid the foundations of personal friendships that are continuing to develop. I found these research dialogue sessions were instrumental in my perceptions of a quality research experience in my honours degree. My perception of the benefits is such that I continue to participate in these dialogue sessions while now undertaking my $\mathrm{PhD}$ studies.

\section{Research Student Lived Experience 2: From Master's Honours to PhD}

The foremost topics that frame my reflections as an RHD student include: my supervisor, the 'how' to, the process and the research outcome. When I began my master's honours research many previous and current students said that finding a supervisor with whom you could work as a team, and thus build a mutually beneficial relationship, was the most important task as it became foundational to the entire experience. I felt I was fortunate as I had already built a strong relationship with a lecturer in the field of my research and who had indicated she would be pleased to work with me. I thought I was set. However, that supervisor went overseas for six months (in the early stages of my 1-year project) and the long-distance communication difficulties proved frustrating, demoralising and stressful. Upon her return the supervisor resigned, but kindly introduced me to an associate professor who, while not a specialist in my field of research, was a specialist in research and the research process. From the first meeting my whole project turned around and was salvageable in time to graduate honourably. I am so extremely fortunate to be able to work with this same supervisor for my PhD. It is so important to have a supervisor who is truly interested in research and its nuances, takes the time to understand their student and can coach in the student's 'language'. Students have to learn how to become adept researchers in order to produce quality work.

At the beginning of their projects, most students have only a superficial understanding of research and 'how' the process works. Research involves much more than simply taking courses about the qualitative or quantitative approaches. From observation, students learn in different ways. I have to be taught, finding it difficult to read between the lines. This instruction, I feel, is a fundamental difference between the approach of my first and second supervisor. My second supervisor took the time to teach me the philosophy behind research, which then explained so much of the process and enabled me to internalise and justify my choices, plus appreciate the literature in a whole new dimension. Halfway through my master's honours, after dog-paddling around in the ocean of research, I was finally shown how to swim. The process of researching has certain steps that are functional, however, it is the nuances of the process that need crafting and that can only be taught by a 'qualified' researcher. For me, the high-end skills such as appreciating the depth and extent of immersion required with qualitative research, the importance of networking with colleagues and the significance of attending forums to hear other researchers' presentations. Once a student truly understands the 'how', the actual process of conducting the research is made easier.

In general, I have found the administrative steps in the process reasonably manageable, however, the steps that involve working with others is my challenge. I thoroughly enjoy reading and learning from the literature. It never ceases to amaze me how my supervisor can recommend readings on most topics I need. I enjoy analysing and writing. While somewhat laborious, I enjoy transcribing, but it is the finding of participants and the joining of network groups where I lose confidence and interest. From the personal development perspective, it is this part of the research process I have needed most. My supervisor has successfully initiated and maintained a research dialogue group at which fellow students and guests share their experiences, concerns and successes. Any topic about research is raised and explored, thereby teaching everyone. Rehearsals for confirmations, participant workshops and the launching of an online survey have proved invaluable from the perspective of allaying fears and gaining from and giving support to colleagues. These dialogue sessions and other network possibilities offered to us are unique opportunities driven my supervisor's quest to deliver a quality research experience for her students. This experience has proven to me that one person's success is assisted by those around them.

The successful outcome of my master's honours thesis was not all encompassing. While obtaining a good grade, I felt sadness in two areas. First, I am so passionate about the topic and was going to show how businesses needed to change their ways. I busily showed how the literature agreed with my perspective and then my participant's reflections also agreed. I was therefore so disappointed to face the reality that dollars, rather than ideology, drive business and particularly marketing decisions. I felt my efforts had been wasted. The second area of sadness was that I felt my work was not worthy of my grade. I felt it was immature, unpolished and rushed. It has taken me some time to consider the positive nature of this lesson. I now have a great appreciation of other students' work and know how much more effort I will willingly put into my $\mathrm{PhD}$. 


\section{Research Student Lived Experience 3: From Master's to PhD Qualifying to PhD}

Thinking about my experiences as a higher-degree research student made me reflect back on why I chose to do further studies in the first place. Being born and raised in Germany, I finished my undergraduate studies in information systems about 15 years ago and had, I would say, a great and successful career within information technology (IT) including running my own internet business. However, I reached a point where I felt burned out, not interested anymore in what I was doing and sometimes even bored, which is not a very good combination when you are responsible for other people's jobs. I needed a change and started looking at different study options with the result of pursuing a master's degree in ecotourism in Australia. This may not sound like a useful continuation of my IT-based career, but for me it was more important to do something in a field that interests me and to attain a degree in an English-speaking country. At that stage, I did not really think further than doing that degree.

I came to Australia in 2005 and began my studies about 2 weeks after I arrived. Although I travelled to and through Australia before my move, settling down and getting ready for studies after a 13-years 'break' was both stressful and exciting. After initial struggles with language and understanding of the study requirements, I was very pleased with managing to achieve good grades for my assignments. The master's degree I pursued was by coursework, but a larger research project was an option, which I happily took on. I really started liking researching for information, articles and analysing, synthesising information and facts. Such processes are similar to processes I learnt within IT, but now the focus was more on the content than on the process itself. Although this research project inspired me to do my $\mathrm{PhD}$, the research experiences I made during my master's are based on a lack of support and instructions by the university and my supervi- sor. I even felt discouraged regarding my $\mathrm{PhD}$ plans and surprised by the lack of interest in students who were keen to do further studies. I guess this only made me aware of how important it is to choose the 'right' supervisor and university to pursue a doctorate.

After choosing a supervisor at another university, my PhD journey started with a further disappointment. Because of the type of German bachelor degree completed and the masters by coursework, I was only accepted into a qualifying program, which lasted 1 year and included some coursework and a major research proposal. Although this added to my study expenses and makes the whole study process longer, in the end I think the qualifying program was a great learning experience and prepared me well for the $\mathrm{PhD}$ program, especially in terms of choosing my paradigm and research approach. Besides this positive experience, I must say it was partly a very frustrating process. Being a research higher degree student, but not accepted into the doctoral program meant no room, no desk, no computer, everything you need to have to organise yourself. Further, qualifying students were not included in the research culture at the university, which meant you have to try to engage with people and build up your own support networks. All together this really makes you feel unqualified, regardless of your previous study, work, or life experiences.

The best support I received during the qualifying program was from my principal supervisor, who included all interested research students, regardless of their status, in research dialogue groups. Especially in the beginning of the qualifying program I felt lonely and isolated, so every opportunity to connect with other students and researchers was more than welcomed. As an international student you usually do not have your family and friends as a support network around or near you, and friendships have to be built up from scratch. Further, as an RHD

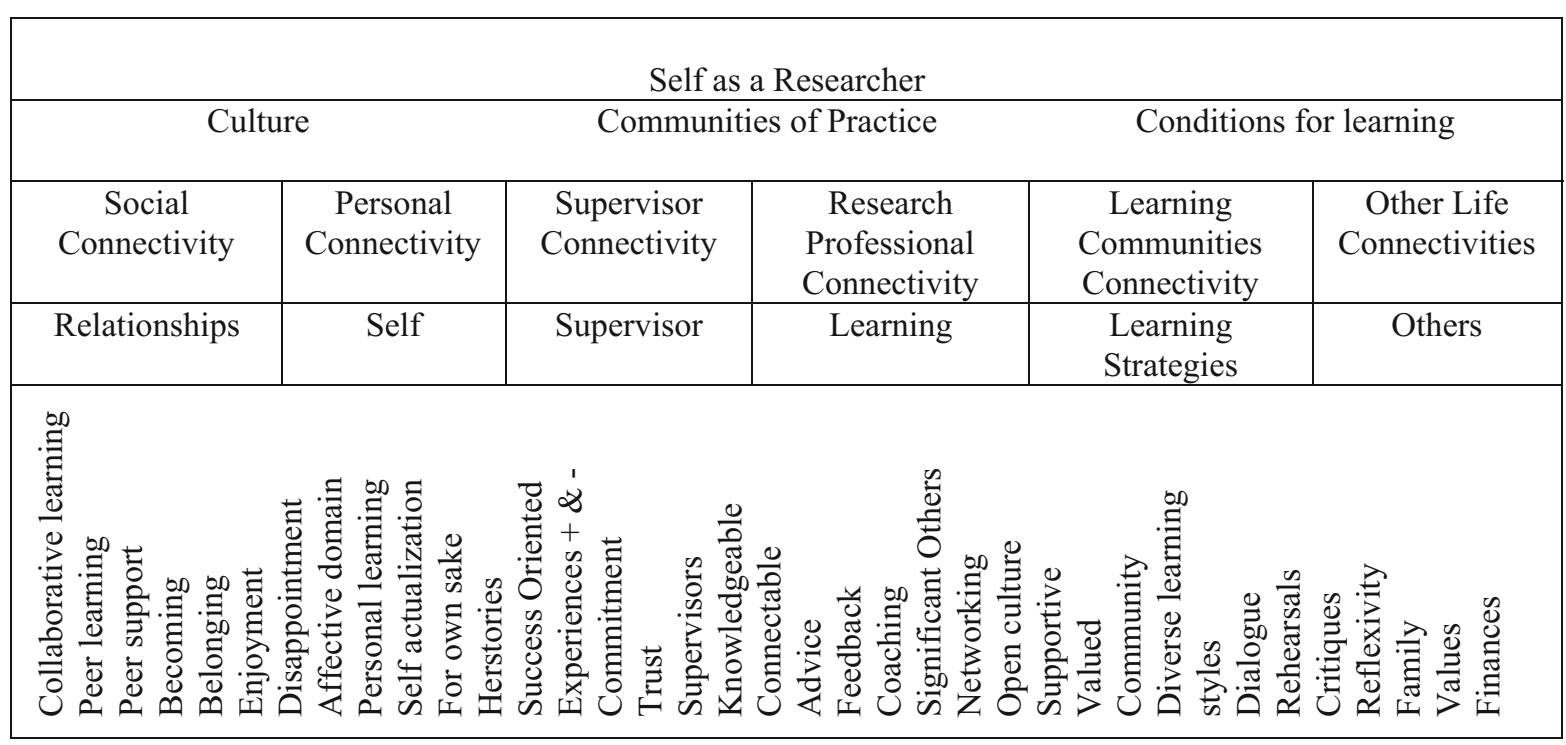

\section{Figure 1}

Overview of grounded theory interpretive phases and process. 
student you are working individually on your own project and connections to other students and staff are limited.

I guess since I am in the $\mathrm{PhD}$ program, receiving all the support of the university and especially sharing a room with other PhD students, I feel more accepted and connected within the university's research environment. For me, this is an important aspect while doing my doctorate. Based on my previous career, I am used to working together with people. Focusing on your own project and basically being the only person who is really engaged in it is a totally different and demanding experience. Continuing to discuss my research within the research dialogue sessions is still a very important part of my social connectedness as well as my academic development. Especially because 'how to do a PhD' and 'becoming a researcher' are more based on learning by doing rather than something taught or instructed. Therefore, having a very supportive and engaging principal supervisor that pushes you further when you think you cannot go any further is the most important aspect within my PhD journey.

\section{Interpreting Research Student Experiences}

A constructivist approach to grounded theory analysis was used to interpret/(re)construct the research student narratives (see Charmaz, 2006; Jennings \& Junek, 2007). This involved researchers identifying key terms in each of the narratives and then framing these as concepts. These concepts were in turn organised into conceptual clusters and subsequently into dominant themes. Figure 1 provides readers with an overview of this interpretive process so that you may 'audit' our meaning-making processes. The interpretive process represented in Figure 1 resulted from numerous iterations and re-iterations and reflexive dialogue.

Based on our interpretations/(re)constructions, a quality research student experience is one where the student is able to experience personal, social, learning community, supervisor and research profession connectivity as well as other life-related connectivities. Moreover, the lived experience of research is holistically constituted, socially situated as well as dynamic and fluid in nature. Change and flux are constants. The complexities of life also cannot be disassociated from the research experience itself. Additionally, conducive learning environments, which incorporate Cambourne's seven conditions for learning, Wenger's communities of practice processes, along with inclusive research cultures, serve to enhance research student experiences - and in the case of these three students, contributed to quality research learning/teaching experiences. Figure 2 provides a diagrammatic representation of our theory. As with any visual representation of complex and changing processes, we recognise that this is a snapshot and that the multiplicity and interactive nature of the processes are portrayed in a limiting two-dimensional manner.

The localised and situated theorising associated with the three student's autoethnographic accounts has synergy with other extant literature presented earlier in this article, as well as additional literature sourced after the interpretation of the autoethnographies. These synergies are presented in Table 2. There are two elements that appear to be underreported in the extant literature: the holistic and socially situated nature of research students' lived experiences, as well as incorporation of communities of practice processes and it is here that this study draws readers' attentions. For in addressing these two elements, universities, students and supervisors will be able to tap in to lesser considered aspects in order to influence the overall quality of research student experience. We acknowledge that, individually and collectively, such practices may be incorporated as praxis elements, we make these comments, however, based on their as yet underreported position in extant literature.

\section{Further Reflections on Research Student Lived Experiences}

Students reported that their current lived experience of research culture and related profession-based learning directly matched 'espoused values' (for example, strate-

Table 2

Research Student Experiences and Synergistic Extant Literature

\begin{tabular}{|c|c|}
\hline Research student experiences & Synergistic extant literature \\
\hline Student self as researcher & Larson \& McNeill (2004); University of Sydney (2004) \\
\hline Personal connectivity & $\begin{array}{l}\text { Knowles (1984, 1990); Phillips (1994), Piercy et al. (2005); Larson \& McNeill (2004); University of } \\
\text { Sydney (2004) }\end{array}$ \\
\hline Social connectivity & Piercy et al (2005); University of Sydney (2004) \\
\hline Learning community connectivity & Wenger (1998); Deem \& Brehony (2000); University of Sydney (2004) \\
\hline Supervisor connectivity & $\begin{array}{l}\text { Conrad (2006, 2003); Hortsmanshof \& Conrad (2003); Golde \& Dore (2001), Kulej \& Park (2008); } \\
\text { Neumann (2003) }\end{array}$ \\
\hline Research profession connectivity & Golde \& Dore (2001); Kulej \& Park (2008); University of Sydney (2004) \\
\hline Other life-related connectivities & $\begin{array}{l}\text { Larson \& McNeill (2004); Maher, Ford, \& Thompson (2004); Kulej \& Park (2008); University of } \\
\text { Sydney (2004) }\end{array}$ \\
\hline Holistic and socially situated nature of experiences & Ashiabor, Taplin, Bryce, Kefallinos, \& Reid (2003) \\
\hline Conducive learning environments & Cambourne (1984); Senge et al. (1999) \\
\hline Communities of practice & Brook \& Fyffe (2004) \\
\hline Inclusive research cultures & $\begin{array}{l}\text { Trocchia \& Berkowitz (1999); Deem \& Brehony (2000); Conrad (2006, 2003); Hortsmanshof \& } \\
\text { Conrad (2003); Kulej \& Park (2008) }\end{array}$ \\
\hline Administrative issues & University of Sydney (2004) \\
\hline
\end{tabular}




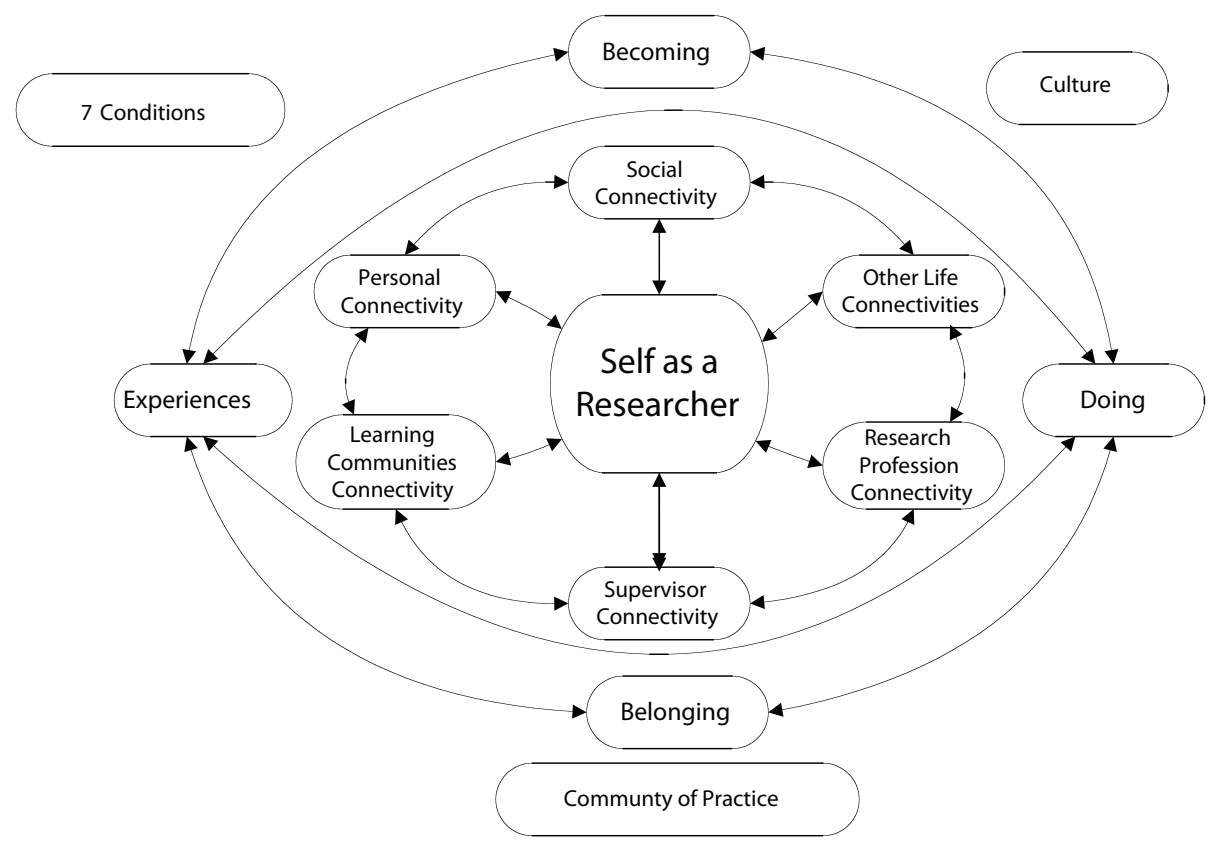

Figure 2

Model of a quality research experience.

gies and goals) and 'artefacts' (evidenced in processes and structures) (Schein, 1992) of their current host institution. This had not always been the case with regard to their collective experiences across programs and institutions. Comparing the composite of each student's total suite of research student experiences highlighted the need for institutions and some educators to shift their 'basic underlying assumptions' (Schein, 1992) (beliefs, feelings, perceptions and thoughts) associated with research training towards more inclusive and socially cognisant processes. Research was experienced as a holistic experience, not a series of compartmentalised snapshot experiences devoid of social connectivity. Student autoethnographies emphasised a need for cohort experiences and development of a sense of belonging to research cultures. Student narratives outlined effective practices for achieving this.

Implicit in the autoethnographies was acknowledgment by research students for a concentration of efforts by institutions and institutional social actors - such as supervisors, researchers, research office personnel - to realise a strong, clearly recognisable and 'experience-able' research culture. In working towards this, institutions and students will be able to provide 'quality' research student learning/teaching experiences. The nature of quality, however, needs to be determined by iteratively and reflexively drawing on the autoethnographies of research students (and supervisors). Using such processes recognises that meaning-making is a socially constructed, situated and fluid process and subsequently further informs andragogy, pedagogy, ethnogogy and praxis.

Based on the autoethnographies interpreted and shared in this article, a quality research student experience provides personal, social, supervisor, research profession, learning communities, and other life connectivities generated through conducive conditions for learning, communities of practice and inclusive research cultures wherein research students experience and do research in order to become researchers and to belong to research communities. Specifically, the three students reported quality research experiences, which were predicated on inclusivity and belongingness.

\section{References}

Alsop, C.K. (2002). Home and away: Self-reflexive auto-/ethnography [Electronic version]. Forum: Qualitative Social Research, 3(3),. Retrieved July 24, 2009, from http://www.utsc.utoronto.ca/ kmacd/IDSC10/Readings /Positionality/auto-eth.pdf

Alvesson, M., \& Sköldberg, K. (2000). Reflexive methodology, new vistas for qualitative research. London: Sage.

Ashiabor, H., Taplin, R., Bryce, M., Kefallinos, E., \& Reid. A. (2003). Redefining our experiences of research through the integration of multiple perspectives for the development of postgraduate research. AARE Newcastle Mini-conference 2003 Proceedings. Retrieved July 24, 2009, from http://www.aare.edu.au/conf03nc/as03021z.pdf

Brook, C., \& Fyffe, J. (2004). Are we comfortable yet? Developing a community of practice with $\mathrm{PhD}$ students at the University of Melbourne. ASCILITE 2004 Conference Proceedings. Retrieved July 24, 2009, from http://dtl.unimelb.edu.au/R/PPKX98H3VE5YJ971PHYR7X1UV4XI KNNS4LIBT6GVTAHP2T 7JXQ-0057 1 ? func $=$ dbin-jumpfull\&object_id=66702\&local_base=GEN01\&pds_handle=GUEST

Cambourne, B. (1984). The origins of teachers' doubts about 'naturalising' literacy education. And some suggestions for easing them. Reading: 1984 and Beyond, Selected Key Papers of the 10th Australian Reading Conference 1984, 2, 17-39.

Charmaz, K. (2006). Constructing grounded theory: A practical guide through qualitative analysis. London: Sage.

Cloke, P., Crang, P., \& Goodwin, M. (1999). Introducing human geographies. London: Arnold.

Conrad, L. (2006). Countering isolation: Joining the research community. In C. Denholm \& T. Evans (Eds.), Doctorates downunder: Keys to success- 
ful doctoral study in Australia and New Zealand (pp. 34-40). Camberwell, Victoria, Australia: ACER Press.

Conrad, L. (2003, July 6-9). Five ways of enhancing the postgraduate community: Student perceptions of effective supervision and support. Proceedings of the HERDSA (Higher Education Research and Development Society of Australasia), Learning for an unknown future: Research and development in higher education. University of Otago, Christchurch, New Zealand.

Deem, R., \& Brehony, K.J. (2000). Doctoral students' access to research cultures: Are some more unequal than others? Studies in Higher Education, 25(2), 149-166.

Fleming, C., \& Fullagar, S. (2007). Reflexive methodologies: an autoethnography of the gendered performance of sport/management [Electronic version]. Annals of Leisure Research, 10(3-4), 238-256. Retrieved July 24, 2009, from http://www98.griffith.edu.au/dspace/bitstream/10072/18851/1/47110 1.pdf

Golde, C.M., \& Dore, T.M. (2001). At cross purposes: What the experiences of today's doctoral students reveal about doctoral education. Wisconsin, USA: The Pew Charitable Trusts.

Groseschl, S., \& Doherty, L. (2000). Conceptualising culture. Cross Cultural Management, 7(4), 12-17.

Harden, R. (2007). Identities in motion: An autoethnography of an African American woman's journey to Burkina Faso, Benin, and Ghana. Unpublished doctoral dissertation, Graduate College of Bowling Green State University. Retrieved July 24, 2009, from http://www.ohio link.edu/etd/send-df.cgi/Harden\%20Renata.pdf?bgsu1182028035.

Hortsmanshof, L., \& Conrad, L. (2003, July 6-9). Postgraduate peer support programme: Enhancing community. Proceedings of HERDSA (Higher Education Research and Development Society of Australia), Learning for the unknown future: research and development in higher education. Christchurch, New Zealand: University of Otago.

Jennings, G.R., \& Junek, O. (2006). Grounded theory: innovative methodology or a critical turning from hegemonic methodological praxis in tourism studies? In I. Ateljevic, N. Morgan \& A. Pritchard (Eds.), The critical turn in tourism studies: Innovative research methodologies (Advances in Tourism Research) (pp. 197-210). Amsterdam: Elsevier.

Jennings, G.R., \& Weiler, B. (2006) Brokering - toward quality tourism experiences. In G.R. Jennings \& N. Nickerson (Eds.), Quality tourism experiences (pp. 57-78). Burlington, MA: Elsevier.

Jennings, G.R., (2009). Methodologies and methods. In T. Jamal \& M. Robinson (Eds.), The Sage handbook of tourism studies. (pp. 672-692). Los Angeles: Sage.

Knowles, M. (1984). Andragogy in action. San Francisco: Jossey-Bass.

Knowles, M. (1990). The adult learner: A neglected species (4th ed.). Houston: Gulf.

Kulej, M., \& Park, C. (2008). Postgraduate research experience survey, 2008. Heslington, UK: The Higher Education Academy.
Maher, M.A., Ford, M.E., \& Thompson, C.M. (2004). Degree progress of women doctoral students: Factors that constrain, facilitate and differentiate. The Review of Higher Education, 27(3), 385-408.

Neumann, R. (2003). The doctoral education experience: Diversity and complexity. Canberra, Australia: Australian Government Department of Education, Science and Training.

Noy, C. (2007). The language(s) of the tourist experience: An autoethnography of the poetic tourist. In I. Ateljevic, N., Morgan \& A. Pritchard (Eds.), The critical turn in tourism studies: Innovative research methodologies (Advances in Tourism Research) (pp. 349-370). Amsterdam: Elsevier.

Offstein, E.H., Larson, M.B., \& McNeill, A.L. (2004). Are we doing enough for today's graduate student?. The International fournal of Educational Management, 18(7), 396-407.

Pelias, R.J. (2003). The academic tourist: an autoethnography. Qualitative Inquiry, 9(3), 369-373. DOI: 10.1177/1077800403009003003.

Phillips, D.J. (1994). Solutions to the dilemmas and concerns of teaching international students in universities. Legal Education Review, 5(1), 47-66.

Piercy, F.P., McWey, L.M., Tice, S., James, E.J., et al. (2005). It was the best of times, it was the worst of times: Doctoral students' experiences of family therapy research training through alternative forms of data representation. Family Process, 44(3) 363-378.

Pondy, L.R. (1989). Thoughts on doctoral education. Fournal of Organizational Change Management, 2(2), 15-17.

Pratt, M.L. (1992). Imperial eyes: Travel writing and transculturation. London: Routledge.

Schein, E. (1992). Organizational culture and leadership. San Francisco: Jossey-Bass.

Schwandt, T.A. (2001). Dictionary of qualitative inquiry (2nd ed.). Thousand Oaks, CA: Sage.

Senge, P.M., Kleiner, A., Roberts, C., Roth, G., Ross, R., \& Smith, B. (1999). The dance of change: The challenge of sustaining momentum in learning organisations. London: Nicholas Brealey.

Trocchia, P.J. \& Berkowitz, D. (1999). Getting doctored: A proposed model of marketing doctoral student socialization. European fournal of Marketing, 33(7/8) 746-760.

Turner, V. (1969). The ritual process. Chicago: Aldine.

Turner, V., \& Turner, E. (1978). Image and pilgrimage in Christian culture: Anthropological perspectives. Oxford: Oxford University Press.

University of Sydney. (2004). The international research student experience: Analysis of comments. Student Research Experience Questionnaire (SREQ). Sydney, Australia: Author.

Wenger, E. (1998). Communities of practice: Learning, meaning, and identity. Cambridge, UK: Cambridge University Press. 